\title{
COVID-19: Biosafety in the Intensive Care Unit
}

\author{
Diego Andrés Díaz-Guio ${ }^{1,2,3}$ (1) Yimmy Díaz-Guio ${ }^{1,2}$ • Valentina Pinzón-Rodas ${ }^{1}$ • Ana Sofía Díaz-Gomez ${ }^{1}$. \\ Jorge Andrés Guarín-Medina ${ }^{4}$ - Yesid Chaparro-Zúñiga ${ }^{5}$ • Alejandra Ricardo-Zapata ${ }^{1}$ • Alfonso J. Rodriguez-Morales ${ }^{6,7}$
}

\author{
(C) Springer Nature Switzerland AG 2020, corrected publication 2020
}

\begin{abstract}
Purpose of Review COVID-19 is a new, highly transmissible disease to which healthcare workers (HCWs) are exposed, especially in the intensive care unit (ICU). Information related to protection mechanisms is heterogeneous, and the infected HCWs' number is increasing. This review intends to summarize the current knowledge and practices to protect ICU personnel during the patient management process in the context of the current pandemic.

Recent Findings The transmission mechanisms of SARS-CoV-2 are mainly respiratory droplets, aerosols, and contact. The virus can last for a few hours suspended in the air and be viable on surfaces for several days. Some procedures carried out in the ICU can generate aerosols. The shortage of respirators, such as the N95, has generated an increase in the demand for other protective equipment in critical care settings.

Summary The probability of transmission depends on the characteristics of the pathogen, the availability of quality personal protective equipment, and the human factors associated with the performance of health workers. It is necessary to have knowledge of the virus and availability of the best possible personal protection equipment, develop skills for handling equipment, and develop non-technical skills during all intensive care process; this can be achieved through structured training.
\end{abstract}

Keywords COVID-19 - SARS-CoV-2 . Cooperative behavior $\cdot$ Personal protective equipment $\cdot$ Biosafety $\cdot$ Critical care unit . Education $\cdot$ Medical

\section{Introduction}

Coronaviruses belong to the family Coronaviridae, which comprise a great number of viruses common in humans and other animals [1]. The severe acute respiratory syndrome coronavirus 2 (SARS-CoV-2), a new Betacoronavirus, is the etiological agent of the coronavirus disease (COVID-19) [2, 3]. SARS$\mathrm{CoV}-2$ is an RNA virus, the seventh in a coronavirus family

This article is part of the Topical Collection on Emerging Tropical Diseases

Diego Andrés Díaz-Guio

andres.diaz@vitalcare.co

1 Education and Simulation Research Group (EdSIMc), Centro de Simulación Clínica VitalCare, 16N street 14-50, Armenia, Colombia

2 Critical Care Department, Hospital Universitario San Juan de Dios, Armenia, Colombia

3 Doctoral Program in Education, Arts and Humanities Faculty, Universidad de Caldas, Manizales, Colombia
4 Critical Care Department, Westküstenklinikum, Heide, Schleswig Holstein, Germany

5 Internal Medicine Department, Hospital Universitario Santa Clara, Bogota, Colombia

6 Public Health and Infection Research Group, Faculty of Health Sciences, Universidad Tecnológica de Pereira, Pereira, Risaralda, Colombia

7 Grupo de Investigación Biomedicina, Faculty of Medicine, Fundación Universitaria Autónoma de las Américas, Sede Pereira, Pereira, Colombia 
able to infect humans. It is $40-140 \mathrm{~nm}$ in diameter $(0.04$ $0.14 \mu \mathrm{m})$ and has a lipid envelop. Its target is angiotensinconverting enzyme 2 (ACE2) $[2,3]$.

This new coronavirus has a high infecting capacity; its basic reproduction number (R0) is variable, possibly between 2 and 3 [4], twice the R0 of swine flu (H1N1) [5], and similar to the 1918 pandemic influenza (Spanish flu) [6]. It has a global distribution; it is also a highly transmissible agent with potentially fatal outcomes. To date, July 12,2020 , it has infected nearly 12.5 million people and caused the death of more than 560,000 patients, including health personnel [7].

For a safe work environment, joint work between workers and employers is required. In the case of health services in the COVID-19 pandemic, this premise is also pertinent. Employers must guarantee resources for the protection of healthcare workers (HCWs), and they must make judicious and rational use of the biosecurity elements available [8].

COVID-19 is a very transmissible disease; its transmission mechanisms are mainly respiratory droplets, aerosolized particles, and contact. However, in the intensive care unit (ICU), some procedures are associated with aerosol production [9]. Most patients present mild symptoms, and 10-30\% need hospitalization in the ICU $[10,11]$, which has exceeded the available resources, even in countries with robust healthcare systems [12]. In low-income countries, the situation could become even worse [13]. Health systems must optimize their resources, prepare their ICUs, and guarantee the protection of those who face the pandemic on the front line [14].

This article aims to show the different strategies to prevent the widespread of the disease to critical care healthcare workers based on the review of the recent literature and the author's experience with the personal protective equipment (PPE) in the care of patients with COVID-19 and work on human factors in crisis management.

\section{ICU Healthcare Personnel: High Risk of Contagion}

COVID-19 can be transmitted person to person through droplets emitted by infected patients when they speak, cough, sneeze, or when a person comes into contact with contaminated surfaces [15]. Most of the procedures that can generate aerosols are executed in the ICU (orotracheal intubation, tracheostomy, CPR, among others), which exposes the personnel to a high risk of contagion [9].

\section{Aerosol Dynamics}

It is necessary to define some concepts of the dynamics of respiratory droplets $(>5 \mu \mathrm{m})$ and aerosols $(<5 \mu \mathrm{m})$ produced by the airways of patients with respiratory disease, and the interaction of these particles with the intensive care unit hospitalization environment. The flow acceleration achieved when coughing can be between 2 and $50 \mathrm{~m} / \mathrm{s}$, and when sneezing can reach up to $100 \mathrm{~m} / \mathrm{s}$ [16]. The emitted gas forms a turbulent, multiphase cloud, which can go up to $8 \mathrm{~m}$ [17]; the aerosolized virus may remain suspended for several hours and be active on surfaces for many days $[18,19]$.

In China, $3.8 \%$ of those infected correspond to health personnel [20]; in Italy, 10-20\% [21, 22]. In Colombia, as of July 12, 2020, 2,633 COVID-19 infected healthcare workers have been reported, which corresponds to $2 \%$ of the total number of infected in the country; $75.3 \%$ were associated with patient care. Most infections have occurred in nursing assistants $(34 \%)$, physicians $(18.5 \%)$, nurses $(13.5 \%)$, administrative staff $(9.3 \%)$, and clean and disinfection workers $(5 \%)$. $0.83 \%$ of infected health personnel have died [23].

\section{Personal Protective Equipment}

Intensive care personnel is more habituated to biosafety protocols. Nonetheless, in this pandemic, several limitations in adherence to infection control guidelines have been evidenced, including the shortage of PPE, poor quality of PPE, unavailability of rooms with antechamber, bathroom, negative pressure and air exchange, shortcomings in training in PPE donning and doffing, frequent changes on management guidelines, and ambiguity of the recommendations [24-26].

The patient may disperse particles that have infectious contents. These particles experience changes with the dynamics of airflow in the room, which can be influenced by the high traffic in the place, the presence of air conditioning, negative pressure, door opening, among others. The droplets are heavy and usually fall on the patient and in his environment. Despite that, they can be dried by air currents leaving the droplet nuclei exposed and able to persist suspended in the air. Viral dose, exposure time, mucosal exposure, and tidal volume are determining factors in the possibility of contamination and HCWs possible infection [16, 27].

The infectious particles can be on the patient, in their environment (fomites), and possibly in the patient's room air. The virus can reach its target site through the eyes conjunctive, nose, and mouth mucosae. The fecal-oral route may be involved, but this has not been proven so far [28]. If we understand these data, we may have an opportunity to prevent the spread of the disease to healthcare workers with specific physical barriers known as personal protective equipment (PPE) [29, 30].

Eye protection can be done by wearing goggles, facial shields, or full-face elastomeric respirators. Mouth and nasal protection are conferred by N95/KN95/FFP2 (filtering face piece) or higher respirators. In the event of a shortage of disposable respirators, half-face or full-face elastomeric respirators with N95 or more top filters can be used. The inspiratory and expiratory seal verification is essential in all respirators before use (Fig. 1).

The protection offered by masks and respirators against particles larger than $0.3 \mu \mathrm{m}$ is a surgical mask: $80 \%$, FFP2: 94\%, N95: 95\%, FFP3: 99.9\%, N100: 99.9\%. It is strongly recommended to verify the National Institute for Occupational 


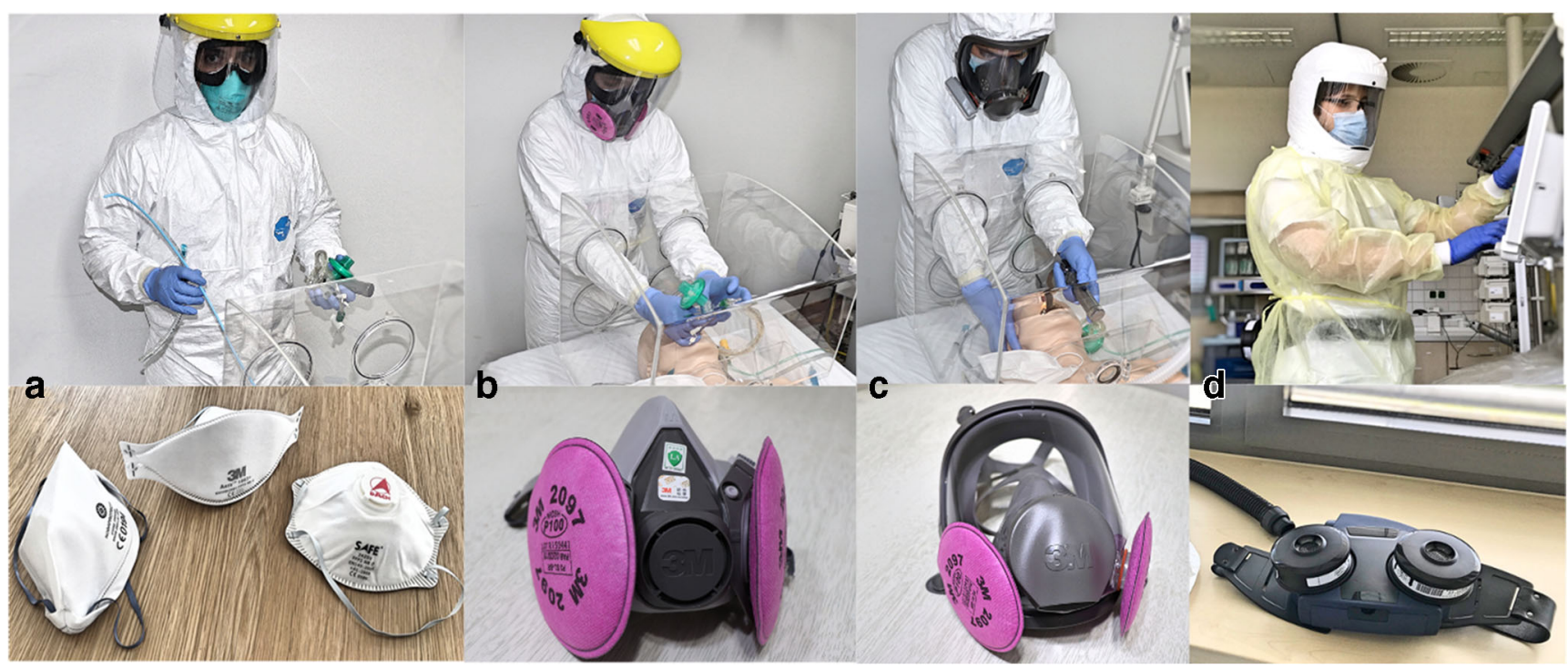

Fig. 1 Respiratory protection: a N95/FFP2; b EHFR: elastomeric half-face respirator; c EFFR: elastomeric full-face respirator; d PAPRs: powered airpurifying respirator system

Safety and Health (NIOSH) quality certification, it must be written on the front of the device.

The WHO recommendations indicate the use of a surgical mask when health personnel is not exposed to aerosolgenerating procedures (AGPs) and N95 when performed [28]. However, the European CDC in high-risk environments recommends the use of FFP 2 or equivalent respirators, and for AGPs recommends FFP3 or equivalent [8, 29], we are aligned with the European recommendations. Nonetheless, to date, there is no robust evidence that medical masks are inferior to N95/FFP2 respirators for protecting healthcare workers against laboratory-confirmed COVID-19 during patients care and non-AGPs [31].

The elastomeric respirator is a valid and increasingly used option due to the shortage of N95/FFP2 respirators [32]. This device can be found in half-face and full-face versions. It is reusable and has different types of filters, although N95 or higher is recommended. It has been shown that short time is required to learn how to use them [33]. In Table 1, we describe the PPE with its use considerations.

\section{Biosafety During COVID-19 Patients Management Process}

While personal protective equipment is an essential part of safety to prevent SARS-CoV-2 transmission, it must be employed appropriately, together with frequent hand hygiene, and mastering specific techniques and non-technical skills like awareness, closed-loop communication, leadership, team working, appropriate resource management, and cognitive aids $[14,34]$. Below, we feature some safety recommendations from patient's admission to the ICU until discharge.

\section{Patient Arrival}

Critically ill patients should be hospitalized in the intensive care unit after a triage process. The referring service (emergency room, operating room, general room, among others) must report the arrival [35]. The hospital should have specific routes for infected patients' transfer [36].

It is recommended that patients be hospitalized in individual rooms with antechamber, bathroom, and negative pressure systems with high-efficiency filters (HEPA) and 12 air changes per hour. Non-intubated patients must wear a surgical mask $[37,38]$.

The number of healthcare workers that meet the patient should be the minimum necessary, and all must use PPE appropriately, with donning and doffing assisted by an external verifier guided by a checklist (Table 2) [30].

\section{Procedures}

The most frequent COVID-19 clinical manifestations are respiratory. Most critically ill patients have respiratory distress and oxygenation disorder [10]; therefore, they need airway management and mechanical ventilatory support in the ICU.

Airway management is considered a high-risk activity for aerosol production; this includes positive pressure mask ventilation, supraglottic device insertion, orotracheal intubation, open airway aspiration, bronchoscopy supported procedures, tracheostomy, and tracheal extubation $[9,38]$. 
Table 1 Personal protection equipment

\begin{tabular}{|c|c|c|c|}
\hline Body part & Protection & Advantages & Disadvantages \\
\hline \multirow[t]{3}{*}{ Eyes } & Goggles & Protection to the eye area & Fog up \\
\hline & & Light weight & Skin pressure injuries \\
\hline & Facial shield & Full-face coverture & Forehead skin injuries \\
\hline \multirow[t]{6}{*}{ Nose/mouth } & N95/FFP2/FFP3 & Hermetic seal & Skin and ear injuries \\
\hline & & Better protection & Communication difficulties \\
\hline & & Disposable & Headache \\
\hline & EHFR & $\begin{array}{l}\text { Antifogging properties } \\
\text { It is not disposable } \\
\text { Longer filter lifetime } \\
\text { Comfortable }\end{array}$ & $\begin{array}{l}\text { Does not protect the patient from user } \\
\text { exhalation } \\
\text { Does not protect eyes } \\
\text { Communication difficulties } \\
\text { Higher cost } \\
\text { Requires decontamination }\end{array}$ \\
\hline & EFFR & $\begin{array}{l}\text { High protection level } \\
\text { Covers entire face } \\
\text { It is not disposable } \\
\text { Longer filter lifetime } \\
\text { Comfortable }\end{array}$ & $\begin{array}{l}\text { Does not protect the patient from user } \\
\text { exhalation } \\
\text { Communication difficulties } \\
\text { Higher cost } \\
\text { Does not allow the use of prescription } \\
\text { glasses } \\
\text { Requires decontamination }\end{array}$ \\
\hline & PAPRs & $\begin{array}{l}\text { High protection level } \\
\text { Comfortable } \\
\text { Useful in high-risk AGPs }\end{array}$ & $\begin{array}{l}\text { Need specific training } \\
\text { Communication difficulties } \\
\text { High risk of contamination when removing } \\
\text { Higher cost } \\
\text { Need large supply of filters } \\
\text { Requires decontamination }\end{array}$ \\
\hline Hands & Double gloves & $\begin{array}{l}\text { Decreases skin } \\
\text { contamination }\end{array}$ & Makes procedures difficult. \\
\hline \multirow[t]{3}{*}{ Body } & Long gown & $\begin{array}{l}\text { Protects against splashes } \\
\text { Easy to put on } \\
\text { Easy to remove }\end{array}$ & $\begin{array}{l}\text { Partial leg exposure } \\
\text { It allows neck exposure } \\
\text { Needs to be complemented by a surgical hat }\end{array}$ \\
\hline & Coverall & $\begin{array}{l}\text { Covers the entire body } \\
\text { Disposable } \\
\text { Integrated hood }\end{array}$ & $\begin{array}{l}\text { Causes diaphoresis, heat, and discomfort } \\
\text { More difficult to doff }\end{array}$ \\
\hline & Shoes cover & $\begin{array}{l}\text { Fluid and particle proof } \\
\text { Lightweight }\end{array}$ & Can become difficult to remove \\
\hline
\end{tabular}

$F F P$, facial filter piece; $E H F R$, elastomeric half-face respirator; $E F F R$, elastomeric full-face respirator; $P A P R S$, powered air-purifying respirator system

\section{Tracheal Intubation}

For tracheal intubation of the patient with suspected or confirmed COVID-19, full and verified PPE must be available. That includes N95/FFP2, FFP3, or equivalent respirators or PAPRs [29, 30], in addition to observing the following recommendations:

\section{Pre-intubation}

- Limit to four HCWs, three within the room (airway, airway assistant, and medication administration), and one external observer.

- Plan for possible approaches and airway devices, ideally a video-laryngoscope.

- Prepare planned airway devices.

- Have airway management checklists available.

- The most experienced professional should intubate.

- Prepare medications outside the room. 
Table 2 Suggested donning and doffing checklist. Additional recommendations: remove personal items (jewelry, watch, etc.); tie up your hair, check that the PPE is complete, in good condition, and in an adequate size

\begin{tabular}{|c|c|c|}
\hline \multicolumn{3}{|c|}{ Donning } \\
\hline Procedure & Procedures & $\mathbf{Y} \mid \mathbf{n}$ \\
\hline 1. Hand hygiene & Put on cover shoes and practice Hand hygiene. & \\
\hline 2. Inner gloves & Put on inner gloves, "second skin". & \\
\hline 3. Gown / coverall & $\begin{array}{l}\text { Gown: secure both ties at the back of the gown. } \\
\text { Coverall: fasten hat and arms of the suit to avoid contact with the } \\
\text { ground. }\end{array}$ & \\
\hline $\begin{array}{l}\text { 4. N95/FFP2/ } \\
\text { FFP3 respirator }\end{array}$ & $\begin{array}{l}\text { Hold the cup with your hand, first raise the lower band, leave below the } \\
\text { ears, then the upper band and leave it above the ears. } \\
\text { Fit the coupling plate over the nose dorsum and perform a fit check } \\
\text { (forced exhalation - forced inspiration). Put on your cap: no skin } \\
\text { exposed. }\end{array}$ & \\
\hline $\begin{array}{l}\text { 5. Goggles /face } \\
\text { shield }\end{array}$ & $\begin{array}{l}\text { Adapt the adjustable base to the size of the head in case of face shield. } \\
\text { Goggles or face shield must be worn over prescription glasses. }\end{array}$ & \\
\hline 6. Outer gloves & Put on the gloves making sure the suit cuffs are covered by the gloves. & \\
\hline 7. Check & STOP: check everything is in place. & \\
\hline \multicolumn{3}{|c|}{ Doffing } \\
\hline Procedure & Procedures & 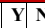 \\
\hline 1. Check & STOP: check everything is in place, watch out for splashes and ruptures. & \\
\hline 2. Hand hygiene & \begin{tabular}{|l} 
Hand hygiene or alcohol gel application. \\
\end{tabular} & \\
\hline 3. Outer gloves & $\begin{array}{l}\text { Remove one glove and squeeze it with the opposite hand, then remove } \\
\text { the other glove from the inside and wrap the one that was initially } \\
\text { removed. }\end{array}$ & \\
\hline 4. Hand hygiene & Hand hygiene or alcohol gel application. & \\
\hline $\begin{array}{l}\text { 5. Goggles /face } \\
\text { shield }\end{array}$ & $\begin{array}{l}\text { Remove the goggles by holding them from the temples. If it is a face } \\
\text { shield, hold it from the posterior side of the adjustable base. }\end{array}$ & \\
\hline 6. Gown / coverall & $\begin{array}{l}\text { Remove the gown by folding it and pulling it away from the body only } \\
\text { by touching the inner part (disinfected side). Include over shoes. }\end{array}$ & \\
\hline 7. Hand hygiene & Hand hygiene or alcohol gel application. & \\
\hline $\begin{array}{l}\text { 8.N95/FFP2/ } \\
\text { FFP3 respirator }\end{array}$ & $\begin{array}{l}\text { Do not touch the front, take the bottom strip, bring it forward and drop it, } \\
\text { then take the top strip and remove the respirator. }\end{array}$ & \\
\hline 9. Inner gloves & Remove gloves. Avoid skin contact with the external side of the gloves. & \\
\hline 10. Hand hygiene & Hand hygiene or alcohol gel application. & \\
\hline
\end{tabular}

\section{During Intubation}

- Intubate in a room with negative pressure.

- Avoid positive pressure ventilation.

- Ensure neuromuscular relaxation.

- Make the first attempt the best attempt.

\section{Post Intubation}

- Verify intubation with a capnograph.

- Fit filter to tracheal tube and ventilator circuits.

- Place closed suction cannula.

- Disinfect the room and surfaces approximately $20 \mathrm{~min}$ after intubating; this may vary depending on the number of air changes per hour in the room.

For intubation and even for planned extubation, in places where negative pressure is not available, acrylic boxes and plastic devices have been used $[39,40]$. They can protect against splashes, possibly aerosols, but this is not clear. These devices can make intubation complex; therefore, the HCWs must be trained in their use.

\section{Tracheostomy}

Before the pandemic, tracheostomies were performed between the 7th and 14th days of endotracheal intubation. However, the median time from intubation to death of COVID-19 patients has been reported to be on the 7th day [41]. Due to the high risk of aerosol production during the tracheostomy, and HCWs' risk of contagion, it seems reasonable to wait for establishing a life prognosis, which could avoid futile procedures if the tracheostomy were performed too early, thus, protecting healthcare personnel [42].

All HCWs participating in the procedure must wear full PPE, which includes PAPRs, N99, or FFP3 respirators [43]. The patient should be sedated and relaxed. Regarding the technique, there is no apparent difference between open and percutaneous tracheostomy. If the percutaneous method is chosen, the one-step dilation technique is preferred [42].

\section{Cardiac Resuscitation}

The consideration of thoracic compressions as an aerosolgenerating procedure has been controversial, due to the United Kingdom's National Healthcare System (NHS) not considering them AGPs [44]; however, the WHO and scientific societies 
consider that they are $[28,37]$; we agree with the latter. Therefore, it is necessary to have all the aerosols precautions in addition to the following recommendations $[45,46]$ :

- Define if the patient is a resuscitation candidate.

- Minimize the number of resuscitation personnel.

- Avoid the maneuver "listening and feeling" to determine to breathe.

- Perform early intubation along with a high-efficiency filter.

- Employ commercial chest compression systems.

\section{Cadaver Disposition}

The mortality of patients admitted to the ICU is elevated, even more so in those requiring mechanical ventilation $[11,41]$. There is no direct evidence on the risk of contagion of healthcare workers who have had contact with the bodies of COVID-19 deceased persons. In a study related to the severe acute respiratory syndrome (SARS) epidemic, there was a reported contagion of $27 \%$ of HCWs that came into contact with corpses [47].

It is recommended that ICU healthcare workers who manage corpses use full PPE following the same recommendations that were described for performing ICU procedures. Tubes and venous and arterial lines should be removed; puncture sites should be disinfected. Corpses should be packed in a double leak-proof bag; the exterior cover, surfaces, and environment must be adequately disinfected.

It is also recommended to avoid direct contact with bodily fluids, contaminated surfaces, transporting stretchers, and make a timely transfer of corpses to the morgue or designated areas. For a recent systematic review on the management of bodies, we refer the reader to Yaacoub et al. [48].

\section{Surface Disinfection}

One of the transmission mechanisms is the contact of HCWs with contaminated surfaces; the presence of SARS-CoV-2 at different sites in the patient's room has been documented [28]. The stability of the pathogen depends on several factors: inoculum size, viral resilience, surface $\mathrm{pH}$, temperature, and humidity of the environment. Persistence has been shown for up to 3 days, depending on the material, being higher in plastic and steel [18]. It is susceptible to heat and standard disinfection methods.

The surface disinfection process should start with cleaning with soap and water or neutral detergents associated with mechanical measures, to remove dirt and reduce the load of pathogens. Second, the use of disinfectants, the WHO recommends hydrogen peroxide, chlorine-based solutions, and alcohol. Efficiency will depend on concentration and exposure time $[49,50]$.

Ethanol $70-90 \%$ requires $30 \mathrm{~s}-1 \mathrm{~min}$ to be effective, chlorine-based products (e.g., hypochlorite) at $0.1 \%$ $(1000 \mathrm{ppm})$ for general environmental disinfection or $0.5 \%$ (5000 ppm) for blood and large body fluid spills require $1 \mathrm{~min}$, and hydrogen peroxide $>0.5 \%$ at least $1 \mathrm{~min}$.

Cleaning and disinfection should start from the least contaminated to the most contaminated; the cleaning material must be labeled and frequently changed due to the risk of contamination. In general, it is recommended in the work areas with patients to clean two to three times a day; objects of everyday use (door handles, keyboards, tables, among others) must be cleaned with higher frequency.

Sanitation and disinfection workers are essential in this pandemic and should receive the best protection available against SARS-Cov-2 and the substances for disinfection use. It is not recommended to spray people or use disinfection chambers for personnel [50].

\section{Behaviors and Non-technical Skills}

At present, most of the people around world are at home protecting themselves with social distancing. Meanwhile, the HCWs must take care of the patients. Anxiety, insomnia, depression, and cognitive overload have been reported in healthcare personnel. They are afraid of contagion, infecting their families, failing, and dying [51].

The use of personal protective equipment, although it is an excellent measure of protection, also presents difficulties that can generate stress and discomfort. Putting them on and removing them is not easy and time-consuming [52]. In this crisis, performing procedures has become more difficult [53]; initially, a feeling of awkwardness is generated; the goggles become foggy; breathing with disposable or elastomeric respirators requires more effort; skin injuries occur; thirst, heat, dizziness, and headaches are felt.

Other difficulties are that most HCWs dress similarly, which limits mutual recognition, added to that respirators significantly limit communication; this has increased the complexity of an already complex disease; the cognitive load of health personnel is already high. Higher cognitive load increases the probability of failure [54], of becoming contaminated and infected. Briefing and debriefing are strongly recommended on each shift and after each severe incident.

Possibly, the most efficient way to decrease cognitive load and improve performance is through training techniques and tasks such as donning and doffing, as well as human factors or non-technical skills such as leadership, communication, and situational awareness. An excellent way to do this is through structured clinical simulation; this includes clear learning objectives, plausibility between the simulated and real context, 
intentional reflection, usage of metacognitive strategies, and evaluation of learning results $[55,56]$.

In low- and intermediate-income countries, the availability of adequate resources for the protection of HCWs is possibly insufficient, which has led health care personnel to improvise their PPE, which puts their safety at risk; therefore, government and administrative levels must guarantee the workers of the ICU the adequate resources.

\section{Conclusions}

COVID-19 is a highly contagious disease, and ICU healthcare workers are very exposed. The main transmission mechanisms are droplets and contact. However, some procedures can generate aerosols. The virus enters the body through the mouth, eyes, and nose. Therefore, biosafety should focus on aerosol precautions and the correct use of full personal protective equipment, surface decontamination, and frequent hand hygiene.

The availability of full personal protective equipment does not indicate absolute safety; there are factors related to the pressure of critically ill care and human factors that are involved with non-safe performance, and that can be improved through training and teamwork.

\section{Compliance with Ethical Standards}

Conflict of Interest The authors declare that they have no conflict of interest.

Human and Animal Rights and Informed Consent Not applicable.

\section{References}

1. Gorbalenya AE, Baker SC, Baric RS, de Groot RJ, Drosten C, Gulyaeva AA, et al. The species severe acute respiratory syndrome-related coronavirus: classifying 2019-nCoV and naming it SARS-CoV-2. Nat Microbiol. 2020;5(4):536-44.

2. Zhu N, Zhang D, Wang W, Li X, Yang B, Song J, et al. A novel coronavirus from patients with pneumonia in China, 2019. N Engl J Med. 2020;382(8):727-33.

3. Wu F, Zhao S, Yu B, Chen YM, Wang W, Song ZG, et al. A new coronavirus associated with human respiratory disease in China. Nature. 2020;579:265-9.

4. Liu Y, Gayle AA, Wilder-Smith A, Rocklöv J. The reproductive number of COVID-19 is higher compared to SARS coronavirus. J Travel Med. 2020;27(2):1-4.

5. Coburn BJ, Wagner BG, Blower S. Modeling influenza epidemics and pandemics: insights into the future of swine flu (H1N1). BMC Med. 2009;7:1-8.

6. Mills CE, Robins JM, Lipsitch M. Transmissibility of 1918 pandemic influenza. Nature. 2004;432(7019):904-6.

7. WHO. Coronavirus disease 2019 - Situation Report - 174 [Internet]. World Health Organization. 2020. Available from: https://www. who.int/docs/default-source/coronaviruse/situation-reports/ 20200712-covid-19-sitrep-174.pdf?sfvrsn=5d1c1b2c 2 .
8. European Centre for Disease Prevention and Control. Safe use of personal protective equipment in the treatment of infectious diseases of high consequence: a tutorial for trainers in healthcare settings. Stockholm; 2014. Available from: https://www.ecdc.europa. $\mathrm{eu} / \mathrm{sites} / \mathrm{default} /$ files/media/en/publications/Publications/safe-useof-ppe.pdf.

9. Cheung JC, Ho LT, Cheng JV, Cham EYKLK. Staff safety during emergency airway management for COVID-19 in Hong Kong. Lancet Respir Med. 2020;8:e19.

10. Huang C, Wang Y, Li X, Ren L, Zhao J, Hu Y, Zhang L, Fan G, Xu J, Gu X, Cheng Z, Yu T, Xia J, Wei Y, Wu W, Xie X, Yin W, Li H, Liu M, Xiao Y, Gao H, Guo L, Xie J, Wang G, Jiang R, Gao Z, Jin Q, Wang J, Cao B Clinical features of patients infected with 2019 novel coronavirus in Wuhan, China. Lancet. 2020;395(10223):497-506.

11. Rodriguez-Morales AJ, Cardona-Ospina JA, Gutiérrez-Ocampo E, Villamizar-Peña R, Holguin-Rivera Y, Escalera-Antezana JP, et al. Clinical, laboratory and imaging features of COVID-19: a systematic review and meta-analysis. Travel Med Infect Dis. 2020;34: 101623.

12. Nacoti M, Ciocca A, Giupponi A, Brambillasca P. At the epicenter of the Covid-19 pandemic and humanitarian crises in Italy: changing perspectives on preparation and mitigation. NEJM Catal Innov Care Deliv [Internet]. 2020; Available from: https://catalyst.nejm. org/doi/full/10.1056/CAT.20.0080

13. Díaz-Guio DA, Villamil-Gómez WE, Dajud L, Pérez- CE, BonillaAldana DK, Mondragon-Cardona A, et al. Will Colombian intensive care units collapse due to the COVID-19 pandemic? Travel Med Infect Dis. 2020; Available from: https://doi.org/10.1016/j. tmaid.2020.101746.

14. Sorbello M, El-Boghdadly K, Di Giacinto I, Cataldo R, Esposito C, Falcetta S, et al. The Italian COVID-19 outbreak: experiences and recommendations from clinical practice. Anaesthesia. 2020;75: 724-32.

15. Cheng ZJ, Shan J. 2019 novel coronavirus: where we are and what we know. Infection. 2020;48:155-63.

16. Wei J, Li Y. Airborne spread of infectious agents in the indoor environment. Am J Infect Control. 2016;44(9):S102-8.

17. Bourouiba L. Turbulent gas clouds and respiratory pathogen emissions: potential implications for reducing transmission of COVID19. JAMA. 2020;323(18):1837-8.

18. Van Doremalen, N: Bushmaker, T; Morris D. Aerosol and surface stability of SARS-CoV-2 as compared with SARS-CoV-1. N Engl J Med 2020;382:1564-1567.

19. Morawska, L; Milton D. It is time to address airborne transmission of COVID-19. Clin Infect Dis. 2020; Available from: https://doi. org/10.1093/cid/ciaa939.

20. $\mathrm{Wu} \mathrm{Z,} \mathrm{McGoogan} \mathrm{JM.} \mathrm{Characteristics} \mathrm{of} \mathrm{and} \mathrm{important} \mathrm{lessons}$ from the coronavirus disease 2019 (COVID-19) outbreak in China: summary of a report of 72314 cases from the Chinese Center for Disease Control and Prevention. JAMA - J Am Med Assoc. 2020;323(13).

21. Livingston E, Bucher K. Coronavirus disease 2019 (COVID-19) in Italy. JAMA. 2020;(March 17). Available from: http://www.ncbi. nlm.nih.gov/pubmed/32181795.

22. Remuzzi A, Remuzzi G. COVID-19 and Italy: what next? Lancet. 2020;395:1225-8.

23. Instituto Nacional de Salud. COVID-19 Colombia | Reporte 17-062020 9:30pm. 2020 [cited 2020 Jun 17]. Available from: https:// www.ins.gov.co/Noticias/Paginas/Coronavirus.aspx

24. Houghton C, Meskell P, Delaney H, Smalle M, Glenton C, Booth $\mathrm{A}$, et al. Barriers and facilitators to healtcare workers' adherence with prevention and control (IPC) guidelines for respiratory infectious diseases : a rapid qualitative evidence synthesis ( review). Cochrane Database Syst Rev. 2020;4.

25. Escalera-Antezana JP, Cerruto-Zelaya PE, Apaza-Huasco M, Miranda-Rojas SH, Flores-Cárdenas CA, Rivera-Zabala L O-MJ. 
Healthcare workers' and students' knowledge regarding the transmission, epidemiology and symptoms of COVID-19 in 41 cities of Bolivia and Colombia. Travel Med Infect Dis. 2020; Available from: https://doi.org/10.1016/j.tmaid.2020.101702

26. Díaz-Guio D, Ospina-vélez J, Ricardo-zapata A. COVID-19: a crisis that requires urgent training measures. Simul Clín. 2020;2(1):6-8.

27. Wilson NM, Norton A, Young FP, Collins DW. Airborne transmission of severe acute respiratory syndrome coronavirus- 2 to healthcare workers: a narrative review. Anaesthesia [Internet]. 2020;(April). Available from: https://onlinelibrary.wiley.com/doi/ full/10.1111/anae. 15093

28. WHO. Transmission of SARS-CoV-2: implications for infection prevention precautions. Scientific Briefing, 2020 July 9 [cited 2020 Aug 21]. Available from: https://www.who.int/news-room/ commentaries/detail/transmission-of-sars-cov-2-implications-forinfection-prevention-precautions.

29. Ecdc. Personal protective equipment (PPE) needs in healthcare settings for the care of patients with suspected or confirmed novel coronavirus (2019-nCoV). 2020 [cited 2020 May 22]. Available from: https:/www.ecdc.europa.eu/sites/default/files/documents/ novel-coronavirus-personal-protective-equipment-needshealthcare-settings.pdf

30. Verbeek JH, Rajamaki B, Ijaz S, Sauni R, Toomey E, Blackwood $\mathrm{B}$, et al. Personal protective equipment for preventing highly infectious diseases due to exposure to contaminated body fluids in healthcare staff. Cochrane Database Syst Rev. 2020;4:CD011621.

31. Bartoszko JJ, Farooqi MAM, Alhazzani W, Loeb M. Medical masks vs N95 respirators for preventing COVID-19 in healthcare workers: a systematic review and meta-analysis of randomized trials. Influenza Other Respir Viruses. 2020;00:1-9.

32. Hines SE, Brown C, Oliver M, Gucer P, Frisch M, Hogan R, et al. Storage and availability of elastomeric respirators in health care. Heal Secur. 2019;17(5):384-92.

33. Pompeii LA, Kraft CS, Brownsword EA, et al. Training and fit testing of health care personnel for reusable elastomeric half-mask respirators compared with disposable N95 respirators. JAMA. 2020;323(18):1849-52.

34. Reader T, Flin R, Lauche K, Cuthbertson BH. Non-technical skills in the intensive care unit. Br J Anaesth. 2006;96(5):551-9.

35. Nates JL, Nunnally M, Kleinpell R, Blosser S, Goldner J, Birriel B, et al. ICU admission, discharge, and triage guidelines: a framework to enhance clinical operations, development of institutional policies, and further research. Crit Care Med. 2016;44(8):1553-602.

36. Goh KJ, Wong J, Tien J-CC, Ng SY, Duu Wen S, Phua GC, et al. Preparing your intensive care unit for the COVID-19 pandemic: practical considerations and strategies. Crit Care. 2020;24(1):215.

37. Alhazzani W, Møller MH, Arabi YM, Loeb M, Gong MN, Fan E, et al. Surviving sepsis campaign: guidelines on the management of critically ill adults with coronavirus disease 2019 (COVID-19). Vol. 46, Intensive Care Medicine. 2020. 854-887 p.

38. Cook TM, El-Boghdadly K, McGuire B, McNarry AF, Patel A, Higgs A. Consensus guidelines for managing the airway in patients with COVID-19: guidelines from the Difficult Airway Society, the Association of Anaesthetists the Intensive Care Society, the Faculty of Intensive Care Medicine and the Royal College of Anaesthetist. Anaesthesia. 2020;75:785-99.

39. Matava C, Yu J, Denning S. Clear plastic drapes may be effective at limiting aerosolization and droplet spray during extubation: implications for COVID-19. Can J Anesth. 2020; Available from: https:// doi.org/10.1007/s12630-020-01649-w.

40. Canelli R, Connor C, Gonzalez M, Nozari A, Ortega R. Barrier enclosure during endotracheal intubation. N Engl J Med. 2020;382:1957-8.

41. Grasselli G, Zangrillo A, Zanella A, Antonelli M, Cabrini L, Castelli A, et al. Baseline characteristics and outcomes of 1591 patients infected with SARS-CoV-2 admitted to ICUs of the Lombardy Region, Italy. JAMA. 2020;323(16):1574-81.

42. Takhar A, Walker A, Tricklebank S, Wyncoll D, Hart N, Jacob T, et al. Recommendation of a practical guideline for safe tracheostomy during the COVID-19 pandemic. Eur Arch Oto-RhinoLaryngology. 2020; Available from: https://link.springer.com/ article/10.1007/s00405-020-05993-x

43. Jessop ZM, Dobbs TD, Ali SR, Combellack E, Clancy R, Ibrahim $\mathrm{N}$, et al. Personal protective equipment (PPE) for surgeons during COVID-19 pandemic: a systematic review of availability, usage, and rationing. Br J Surg. 2020; Available from: https://doi.org/10. 1002/bjs.11750.

44. NHS. COVID-19: infection prevention and control guidance. 2020 [cited 2020 Jun 20]. Available from: https://assets.publishing. service.gov.uk/government/uploads/system/uploads/attachment data/file/881489/COVID-19_Infection_prevention_and_control_ guidance_complete.pdf

45. Couper K, Taylor-Phillips S, Grove A, Freeman K, Osokogu O, Court R, et al. COVID-19 in cardiac arrest and infection risk to rescuers: a systematic review. Resuscitation. 2020;151:59-66.

46. ILCOR. Covid-19 practical guidance for implementation. 2020 [cited 2020 May 24]. Available from: https://www.ilcor.org/covid-19

47. Liu W, Tang F, Fang LQ, De Vlas SJ, Ma HJ, Zhou JP, et al. Risk factors for SARS infection among hospital healthcare workers in Beijing: a case control study. Trop Med Int Heal. 2009;14(SUPPL. 1):52-9.

48. Yaacoub S, Schünemann HJ, Khabsa J, Harakeh AE, Khamis AM, Chamseddine F, et al. Safe management of bodies of deceased persons with suspected or confirmed COVID-19 : a rapid systematic review. BMJ Glob Heal. 2020:e002650.

49. Pagliano P, Kafil HS. Protection and disinfection policies. Le Infez Med. 2020;2:185-91.

50. World Health Organization (WHO). Cleaning and disinfection of environmental surfaces in the context of COVID-19: interim guidance. 2020 [cited 2020 May 27]. Available from: https://www.who. int/publications-detail/cleaning-and-disinfection-of-environmentalsurfaces-inthe-context-of-covid-19

51. Pappa, S; Ntella, V; Giannakas, T; Giannakoulis, V.G; Papoutsi, E; Katsaounou P. Prevalence of depression, anxiety, and insomnia among healthcare workers during the COVID-19 pandemic: a systematic review and meta-analysis. Brain Behav Immun. 2020; Available from: https://doi.org/10.1016/j.bbi.2020.05.026.

52. Mumma JM, Durso FT, Ferguson AN, Gipson CL, Casanova L, Erukunuakpor K, et al. Human factors risk analyses of a doffing protocol for Ebola-level personal protective equipment: mapping errors to contamination. Clin Infect Dis. 2018;66(6):950-8.

53. Díaz-Guio Y, Salazar DF, Montoya F, Cimadevilla-Calvo B, DíazGuio D. Difficult airway in the critically ill patient: much more than technical skills. Acta Colomb Cuid Intensivo. 2018;18(3):190-8.

54. Pawar S, Jacques T, Deshpande K, Pusapati R, Meguerdichian MJ. Evaluation of cognitive load and emotional states during multidisciplinary critical care simulation sessions. BMJ Simul Technol Enhanc Learn. 2018;4(2):87-91.

55. Díaz-Guio DA, Ruiz-Ortega FJ. Relationship among mental models , theories of change, and metacognition : structured clinical simulation. Colomb J Anesthesiol. 2019;47(14):113-6.

56. Díaz-Guio DA, Ricardo-Zapata A, Ospina-Velez J, GómezCandamil G, Mora-Martinez SR-MA. Cognitive load and performance of health care professionals in donning and doffing PPE before and after a simulation-based educational intervention and its implications during the COVID-19 pandemic for biosafety. Infez Med. 2020;28(Suppl 1):111-7.

Publisher's Note Springer Nature remains neutral with regard to jurisdictional claims in published maps and institutional affiliations. 